\title{
Reforming Australian Local Government: Forced or Voluntary Amalgamations?
}

\author{
Brian Dollery
}

$\mathbf{M}$

ICROECONOMIC reform in Australia has already had a substantial impact on the management of the Commonwealth public service. It has also

had significant effects on the operations of most State bureaucracies, notably in Victoria. However, microeconomic reform is much less advanced in local government. This problem is well recognised. For instance, the Industry Commission (1996:164) has observed that

Local governments generally enjoy monopoly control over basic services and their businesses are rarely exposed to competitive pressures. Little data are available to gauge their performance. However, there is a widespread perception of considerable room for improvement.

The comparative lack of microeconomic reform undertaken by local government can be ascribed to various factors. First, the local government sector is small relative to its State and Commonwealth counterparts (see Table 1).

\section{Table 1}

Australian Commonwealth, State and local government percentage shares of total government revenue and outlays, 1994-95

\begin{tabular}{lcc}
\hline Government sector & Total revenue $^{a}$ & Total outlays $^{b}$ \\
\hline Commonwealth & 72 & 54 \\
State/Territory & 24 & 42 \\
Local & 4 & 5 \\
\hline
\end{tabular}

aTotal revenue excludes transfers between levels of government.

bShares do not add to 100 per cent due to rounding.

Source: Industry Commission (1996, Table 2.1).

Brian Dollery is Associate Professor of Economics and Research Fellow in the Centre for Local Government at the University of New England. 
Given the size of the local government sector, it can readily be appreciated why policy-makers directed their initial efforts at the larger State and federal governments.

Second, systematic change would be harder to achieve in local government in Australia, comprising as it does some $\mathbf{7 7 5}$ councils of varying size and importance, than in its much more cohesive and compact State and Commonwealth counterparts.

Nevertheless, considerable gains could flow from the comprehensive reform of local government in Australia. After all, in 1995 it spent in excess of $\$ 10.5$ billion and employed around 156,000 people (Johnstone, 1995:13). This has been recognised by both the federal government and several State and territory governments. For instance, the then Commonwealth Minister for Local Government, Warwick Smith (1996:1), noted in his address to the National General Assembly of the Australian Local Government Association on 3 December 1996 that

All governments must anticipate and react to continual change and respond to rising pressures from the community, business and government sectors to improve efficiency and effectiveness of their services. Local government is no exception.

The Minister went on to identify the nature of the reforms envisaged by the Commonwealth government. These included regulatory reform, benchmarking and performance indicators, competitive tendering and contracting, competition policy, and restructuring.

Restructuring, or amalgamation, is the most controversial item on the agenda of Australian local government reform. Yet the presumption that enforced amalgamations of small municipal councils will necessarily give rise to substantial economies of scale remains unproven. Studies in Australia to date have admittedly been inadequate in depth and breadth; but the American evidence indicates that larger units tend to be associated with proportionately higher spending than smaller units. Moreover, if the argument over amalgamation is extended from economics to include issues such as communities of interest, voter representation, local democracy, participation and vibrancy, then it is further weakened. Accordingly, while more research in greater depth is urgently required, it would be prudent at this stage to adopt the voluntary approach to amalgamations pioneered by New South Wales, and to explore enhanced 'resource sharing' such as already successfully occurs with regional libraries, waste disposal, joint purchasing arrangements, and so forth.

\section{The Extent of Local Government Reform in Australia}

Structural change in local government involves amalgamations of existing councils, boundary changes, voluntary cooperation and joint action between local authoriies.

Local government in Australia is essentially a creature of State legislation and the views of State governments on amalgamation are decisive. Two generic approaches to amalgamation, which has recently occurred in most States, are evident: 
the voluntary approach, as adopted in New South Wales, and the compulsory approach, as adopted in Victoria. Current Commonwealth policy seems to favour the Victorian approach. In practice, most States have adopted an approach that falls somewhere between these two extremes. Enthusiasm for amalgamation appears greatest in Victoria, resistance to it most pronounced in New South Wales and Western Australia (Gerritsen \& Osborn, 1997; Kiss, 1997; Wensing, 1997).

Under the auspices of the Local Government Board inaugurated in May 1993, the number of local governments in Victoria has been reduced from 210 to 78 . Similarly, under the Local Government Boundary Board in South Australia, 63 new councils have been incorporated, with the total number of councils falling from 118 to 81. Queensland's Office for Local Government has overseen the amalgamation of 16 local government areas into seven councils, along with boundary changes to a further 16 councils. Under the Local Government Act 1996, Western Australia's 142 local authorities have made submissions on rationalisation procedures which are presently being considered. During 1992-94, the number of local governments in Tasmania fell from 46 to 29 in a program carried out by the Tasmanian Local Government Board. By contrast, New South Wales has yet to initiate major restructuring. However, between 1946 and 1982 the number of municipalities in New South Wales was reduced from 289 to $175{ }^{1}$ which may ease the pressure for local government restructuring in that State.

\section{Assessing the Impact of Amalgamations}

It is too early to determine the full impact of these amalgamations. Moreover, few empirical studies have been undertaken; and the little work that has been done has focused exclusively on the economic impact of amalgamation. Roger Hallam, formerly Victoria's Local Government Minister, has authored two reviews of his government's local government reform program (Hallam, 1994, 1995a), both of which examine efficiency rather than political issues like access, participation and representation. He has argued that in economic terms Victorian restructuring has been very successful:

A worst-case scenario could have been small, inefficient and expensive councils... The individual targets set for councils were based on the findings of the Local Government Board and were determined after consultation with the councils. Councils were given a three-year period in which to achieve the targets, which represented aggregate savings of between $\$ 362 \mathrm{~m}$ and $\$ 395 \mathrm{~m}$ across the 78 councils. To my delight, and relief, in September I was able to announce that based on the council budgets, they would achieve, in this first year, an aggregate savings of about 90 per cent of the ultimate target. (Hallam, 1995b:68)

\footnotetext{
${ }^{1}$ It has since risen to 177 .
} 
Chapman (1995) found that Tasmanian amalgamations lowered administration costs considerably. However, he noted that his study did not deal with effectiveness and urged caution in interpreting his findings.

Warwick Smith (1996:5) shared the assumption that significant economies of scale and scope exist in local government that can be captured by amalgamating small councils into larger consolidated local authorities:

Where it has occurred, structural reform of local government has provided significant economic benefits to the community. Studies suggest that some of the measurable benefits of structural reform include:

- lower administration costs;

- lower costs of representation;

- increased purchasing power and better use of plant and equipment; and

- a more diverse funding base.

Moreover, the Commonwealth government views amalgamation as the most effective way of enhancing the efficiency of Australian local government (Smith, 1996: 6):

[D]espite the best results which benchmarking and competitive tendering can produce, perhaps the biggest boost to improved efficiency in Local Government can come from a reduction in the number of Councils. There is no doubt in my mind that efficiencies will result from fewer but larger councils.

Enthusiastic support for amalgamation on economic grounds exists also in academic and business circles. For example, the Property Council of Australia has 'claimed that local councils in NSW (particularly in the Sydney Metropolitan Region) were too fragmented, inefficient and parochial, which provided a framework for substantial diseconomies in service delivery and public administration' (Local Government and Shires Associations of New South Wales, 1997:13). Similarly, Soul (1997:6) has argued that 'from any objective assessment, small municipalities hold little economic political or social advantage, and the institution of local government, in its present form, does little to advance the public interest or indeed, its own long-term interests'.

Arguments against amalgamation typically focus on the purported threat it poses for local government democracy. Reduced employment is sometimes also cited, especially in small rural communities where councils are often the largest employer (Vince, 1997). As Warwick Smith (1996:6) has put it,

...structural reform may have some perceived negatives and some of the concerns expressed include: 
- diminished communities of interest;

- diminished voter representation;

- dominance of one area over another, and associated with this, the loss of identity;

- some loss of local government; and

- initial, mostly one-off, financial costs of implementing the reform process.

Here, however, my concern is solely with the claim that the amalgamation of existing small councils into larger local government authorities enhances economic efficiency and effectiveness. The argument has two dimensions: theoretical considerations deriving from the theory of fiscal federalism; and empirical evidence from the international literature.

\section{Theoretical Considerations}

'Fiscal federalism' refers to the division of taxing and expenditure powers among the different levels of government comprising a federation. The economic theory of fiscal federalism, derived largely from Oates (1972), provides insights into the consequences of different arrangements for distributing responsibility for supplying public goods and services among various levels and sizes of government and for differential financing arrangements. The theory gives rise to the 'correspondence principle', which stipulates that the size of a particular government should correspond to the area of benefit flowing from the goods it provides to citizens. Moreover, each public good should be provided by the smallest (that is, lowest-level) government consistent with the absence of spatial spillovers into other regions.

The concept of a 'benefit region' is crucial to the application of the correspondence principle. Almost all public goods have geographically limited areas in which they confer benefits on citizens. For instance, while some public goods, like national defence, have a nationwide benefit region, others, such as streetlighting, have severely localised benefit regions. In democratic societies, citizens of specific benefit regions vote for the services they want and should be obliged to pay for these services. Thus, services which are nationwide in their benefit incidence (like defence forces) should be provided nationally; services with regional benefits (such as highway systems) should be provided regionally; and services with local benefits (like streetlights and pavements) should be provided locally. The notion of the benefit region provides the basis for the concept of an optimal community size which underlies arguments for amalgamation.

The theory of fiscal federalism holds that the optimal size of governments providing a given range of services is determined by the size of the benefit region in accordance with the correspondence principle. But local public goods may have benefit regions of different sizes, some of which will extend into the jurisdictions of adjacent local governments. Such spillovers have at least two important policy implications. First, they create a prima facie case for the joint provision of the local public good in question by adjacent local governments. Second, they create a prima 
facie case for 'matching grants' from higher levels of government in proportion to the extent of the spillovers.

However, such spillovers do not necessarily provide a case for the amalgamation of adjacent councils. The primary reason for this is quintessentially economic and independent of non-economic concerns about the loss of local democracy that allegedly flows from local government amalgamations. Local public services vary greatly in their economic characteristics, like economies of scale and benefit regions. This has important implications for determining optimal public service provision in local government. For example, it is highly unlikely that the optimal service district for fire protection services will coincide, or even resemble, optimal service districts for, say, refuse collection, public parks, or sewage treatment services. It follows on theoretical grounds that a single common service district for even a relatively small number of local public services resulting from the amalgamation of small councils may not be efficient, even if any positive gains in administrative efficiency are included. This argument has some interesting policy implications for contemporary local government in Australia.

\section{Empirical Considerations}

As already observed, little empirical work has been undertaken on the economic effects of amalgamation in Australian local government. Moreover, despite extensive structural reform in Canada, New Zealand and the United Kingdom, surprisingly little empirical evidence has been gathered in these countries on the question of whether small or large local government units are more efficient in local public good delivery. For instance, Boyne (1992:355) has argued that in the United Kingdom an 'empirical vacuum' surrounds local government restructuring since 'hardly anything is known about the consequences of structural change'. Fortunately, considerable research effort has been devoted to the economic consequences of amalgamation in the United States, which can provide some empirical guidance on the issue of amalgamation.

Two kinds of economies can result from the amalgamation of small councils into larger local government authorities. First, economies of scale can arise, as average production costs fall with increasing output. In the context of local govenment amalgamation, economies of scale would need to generate a per capita reduction in average production costs to be meaningful. Second, economies of sccpe (the financial advantages which accrue by providing a range of goods and services through a single organisation rather than through several organisations) often stem from the shared attribution of administrative and other 'overheads' amongst many services.

Table 2 summarises some of the evidence on these economies in the United States. 'Fragmentation' refers to the number of separate units in a local government system. 'Horizontal fragmentation' refers to the number of governmental units in a given tier of government, like local government. By contrast, 'vertical fragmertation' refers to the number of governmental units in a governmental hierarciy. 'General fragmentation' refers to both horizontal and vertical fragmentation. A 
process of local government amalgamation would thus reduce horizontal fragmentation, but not necessarily vertical fragmentation. It follows that amalgamation would also decrease the degree of general fragmentation. Table 2 summarises the findings of 25 studies on the economic effects of differential degrees of fragmentation on the costs of service delivery in American local government:

Table 2

Economies of scale in US local government service delivery

\begin{tabular}{lcccc}
\hline \multirow{2}{*}{$\begin{array}{l}\text { Type of } \\
\text { fragmentation }\end{array}$} & Number of studies & \multicolumn{4}{c}{ Effects of fragmentation on costs } \\
\cline { 3 - 5 } & & Higher & Insignificant & Lower \\
& 11 & 7 & & \\
\hline Horizontal & 14 & 8 & 12 & 9 \\
General & & & & \\
\hline
\end{tabular}

Source: Adapted from Boyne (1992:Tables 3 \& 5).

This evidence tells against both official policy and conventional wisdom about the efficiency of large local governments in Australia. For instance, highly horizontally fragmented local governments spent less in 13 cases compared with higher spending in only seven cases. Similarly, highly generally fragmented local authorities spent more in eight cases and less in nine cases, with twelve spending about the same as less fragmented systems. Boyne (1992:252) himself drew the following conclusions after reviewing this evidence:

In sum, the broad pattern of the evidence suggests that lower spending is a feature of fragmented and deconcentrated local government systems. By contrast, consolidated and concentrated structures tend to be associated with higher spending. This implies that the technical benefits of large units with big market shares, such as economies of scale and scope, are outweighed by competitive and political costs, such as disincentives towards fiscal migration and problems of public scrutiny.

In a comparable but broader survey of the international empirical evidence on scale economies, which included state, regional and local governments, Bahl and Vogt (1975:13-14) concluded as follows:

[M]ost positive findings of scale economies are based on statistical results that show a negative relationship between population size and per capita expenditures. There are great statistical and theoretical problems with interpreting such results as showing scale economies, and about as many studies that find a negative relationship find a positive one. 


\section{Policy Implications}

Economic arguments provide support for the voluntary approach to amalgamations adopted by New South Wales. There are no sound a priori reasons for assuming that similar benefit regions exist for the range of services typically provided by councils. So although economies of scope probably flow from amalgamation, there is no theoretical presumption that economies of scale will result. Moreover, available international evidence is ambiguous on the question of economies of scale and may indicate smaller councils could be more efficient.

This suggests that public policy-makers should seek to provide the legislative framework to facilitate resource sharing or cooperative interaction between local government authorities. For example, if a constellation of neighbouring existing councils (who presumably possess the best knowledge of local circumstances) believes that some service can be provided more cheaply through joint provision, then State and federal governments should encourage cooperation. It is by no means obvious that resource-sharing along these lines in any way necessitates the political amalgamation of participating councils. Accordingly, existing local government democracy is thus not incompatible with the achievement of economies of scale.

The feasibility of resource-sharing arrangements in Australian local government does not have to be demonstrated: a long history of cooperative action already exists. Examples include regional libraries, regional waste operations, bulk purchasing agreements, and sharing specialist and technical staff amongst adjacent councils (NSW Department of Local Government, 1995; Grant \& Payne, 1997).

The views of the local government community itself are crucial in the formulation of any rational policy prescriptions for the sector and at present it is difficult to ascertain these views. However, the Australian Institute of Urban Studies has commissioned the Centre for Local Government at the University of New England to investigate this question. Although it is too early to anticipate the findings of their research, policy-makers no doubt await their report with considerable interest.

\section{References}

Bahl, R. \& W. Vogt (1975), Fiscal Centralisation and Tax Burdens, Ballinger, Cambridge, Mass.

Boyne, G. (1992), 'Local Government Structure and Performance: Lessons from America', Public Administration 71: 333-57.

Chapman, R. (1995), 'Amalgamations, Modemisations, and Efficiency Gains: The Tasmanian Experience', unpublished paper presented to the National Conference of Local Government Grants Commissions, Canberra (November).

Gerritsen, R. \& D. Osborn (1997), 'Reform of Local Government in Australia', pp. 51-112 in Council of Local Government Authorities for International Relations, Comparative Study on Local Government Reform in Japan, Australia and New Zealand, Japan Local Government Centre, Sydney.

Hallam, R. (1994), Minister's Review, Local Government in 1994: It's Coming Together, Victorian Department of Local Government, Melbourne. 
- (1995a), Minister's Review, Local Government in 1995: First Fruits of Reform, Victorian Department of Local Government, Melbourne.

- (1995b), 'From Theory to Practice: The Victorian Local Government Reform Process', pp. 64 76 in P. McDermott, V. Forgie \& R. Howell (eds), An Agenda for Local Government, Massey University, Palmerston North (Local Government Sudies Occasional Paper Series No. 2).

Industry Commission (1996), Stocktake of Progress in Microeconomic Reform, AGPS, Canberra.

Johnstone, M. (1995), 'The Economic Significance of Local Government in Australia', pp. 12-23 in Council of Local Government Authorities for International Relations, The Role of Local Government in Economic and Regional Development, Japan Local Government Centre, Sydney.

Kiss, R. (1997), Governing Local Communities: Top Down or Bottom Up? The Case of Victoria, unpublished paper presented to Conference on Evaluating Local Government Restructuring, University of Tasmania (17-18 April).

Local Government and Shires Association of New South Wales (1997), Voluntary Structural Reform in NSW Local Government, Greg Hoffman Consulting Pty Ltd, Everton Park.

New South Wales Department of Local Government (1995), Resource Sharing for Local Government, Sydney (Practice Note No. 12).

Oates, W. (1972), Fiscal Federalism, Harcourt Brace Jovanovich, New York.

Smith, W. (1996), 'Focus on Change in Local Government Over the Next Five Years', Address to National General Assembly of Australian Local Government Associations, Canberra (3 December).

Soul, S. (1997), 'Local Government: The Patrons of Waste', Local Govemment Management, June: 6-8.

Vince, A. (1997), 'Amalgamations', pp. 151-71 in B. Dollery \& N. Marshall (eds), Australian Local Government: Reform and Renewal, Macmillan, Melbourne,

Wensing, E. (1997), Systemic Reform or Administrative Update? Recent Legislative Changes in Local Government Around Australia, unpublished paper presented to Conference on Evaluating Local Government Restructuring, University of Tasmania (17-18 April).

The author would like to thank two anonymous referees for helpful comments on an earlier draft of the article. 